INTERDISCIPLINARIA ARCHAEOLOGICA NATURAL SCIENCES IN ARCHAEOLOGY

\title{
Rituals, Hoards and Travellers? Archaeometry of the Iron Age Bronze Wheel Amulets
}

\author{
Alžběta Danielisováa ${ }^{\mathrm{a}}$, Daniel Bursák ${ }^{\mathrm{a}}$, Ladislav Strnad ${ }^{\mathrm{b}}$, Jakub Trubačb, \\ Hana Čižmářovád, David Daněček ${ }^{\mathrm{a}, \mathrm{c}}$, Kamil Smíšek ${ }^{\mathrm{c}}$ \\ anstitute of Archaeology CAS, Prague, Letenská 4, 118 01, Prague 1, Czech Republic \\ ${ }^{b}$ Institute of Geochemistry, Mineralogy and Mineral Resources, Faculty of Science, Charles University, Albertov 6, 128 43, Prague 2, Czech Republic \\ 'Středočeské muzeum v Roztokách u Prahy, Zámek 1, 252 63, Roztoky, Czech Republic \\ 'Moravské zemské muzeum, Archeologický ústav, Zelný trh 6, 659 37, Brno, Czech Republic
}

\section{ARTICLE INFO}

\section{Article history:}

Received: $1^{\text {st }}$ April 2020

Accepted: $9^{\text {th }}$ July 2020

DOI: http://dx.doi.org/10.24916/iansa.2020.1.3

\section{Key words}

Iron Age

Central Europe

amulets

coin hoards

fahlores

trace elements

lead isotopes

\begin{abstract}
A B S TRACT
This paper aims to discuss the origin and significance of the so-called spoked-wheel amulets from the late Iron Age ( $3^{\text {rd }}$ to $1^{\text {st }}$ century $\mathrm{BC}$ ). The type with eight spokes, which most resembles a real chariot wheel, was discovered to be made of a specific alloy containing a large amount of lead and a significant amount of antimony, plus traces of silver and arsenic. This combination of elements signifies the use of a copper known as fahlore (tetrahedrite). Its use in Bohemia after the early Bronze Age is rarely observed, if at all. These amulets are therefore a conspicuous exception. Research in Bavaria has revealed other objects made from fahlore copper. Another connection to Bavaria may be indicated by coin hoards accompanied by bronze closure rings of a similar alloy design. Other cases may suggest that antimony was added as a separate component. Here we discuss the composition and provenance of these objects from the perspective of compositional and lead isotope analysis.
\end{abstract}

\section{Introduction}

Wheel rings or spoked-wheel amulets are a ubiquitous and popular part of the material culture of the La Tène period. They occur from the $5^{\text {th }}$ century BC onwards, from France to Hungary, across the vast territory of the La Tène culture. The symbolism of wheel amulets remains unexplained. They are usually associated with Sun symbology, as chariots or wheels represented the Sun carriage from the Bronze Age (Green, 1984). Another common association is with other celestial bodies or phenomena, typically thunder (Green, 1986).

In material culture, spoked wheels were most probably used in personal jewellery, perhaps as amulets or special symbols, as is suggested by their depiction on Celtic coins (e.g. Manching, cf. van Endert, 1991) and evidence from burials since the early La Tène (Werner, 1979; Hecht et al.,

*Corresponding author. E-mail: danielisova@arup.cas.cz
1991; Stöckli, 1975). They were often worn as pendants on necklaces or suspended from brooches on bronze chains (e.g. numerous finds from the oppidum of Stradonice; Píč, 1903).

In central Europe, a significant concentration was observed at the oppidum of Stradonice (Figure 1; Píč, 1903; Kysela and Venclová, 2018), and at Manching (van Endert, 1991), which suggested that the amulets were typical oppida objects; they had first been described as such in Déchelette's well-known comparative table (1914). In recent years, however, they have been observed in increasing numbers in the countryside, largely as a result of the increased use of metal detectors (Čižmářová, 2014; Danielisová et al., 2018a). They are now known to be present at almost every site from the middle to the late La Tène period (i.e. $3^{\text {rd }}$ to $1^{\text {st }}$ century BC) with a particular profusion during the "oppida period" ( $2^{\text {nd }}$ to $1^{\text {st }}$ century $\left.\mathrm{BC}\right)$.

The spoked wheels differ in size, shape, and number of spokes (Čižmářová, 2014). The basic and typologically most homogeneous group comprises the eight-spoked wheels 

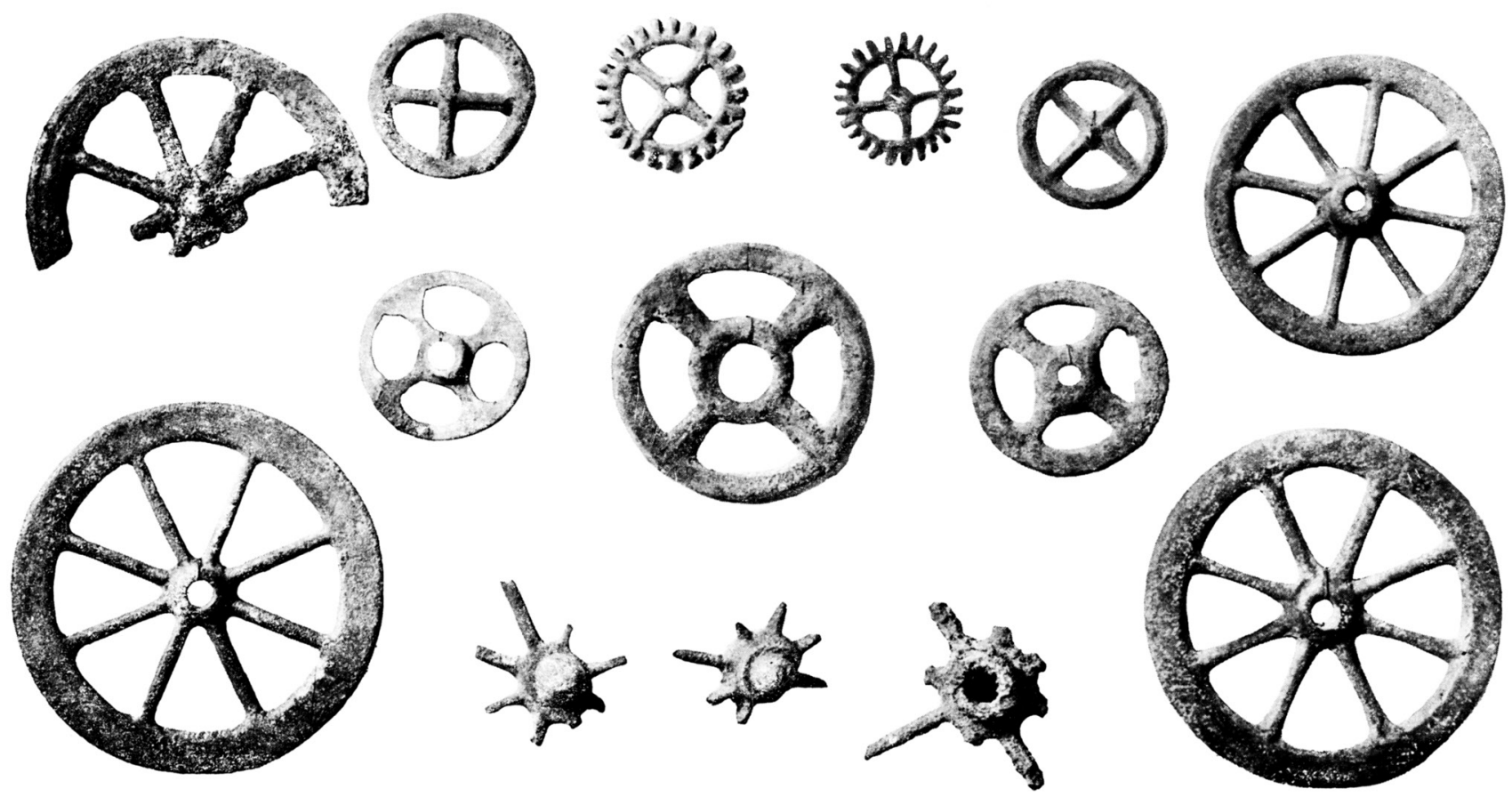

Figure 1. Types of wheel amulet from the La Tène period (the oppidum of Stradonice), after Píč, 1903.

which imitate chariot wheels. They are usually made entirely from lead or from a heavily-leaded alloy (Schwab, 2011). The eight spokes are a regular feature; sometimes there are multiples of eight, as with the sixteen-spoked wheel depicted on a Gundestrup cauldron (Green, 1986). Four- and sixspoked wheels make up a larger and more heterogeneous group. These wheels appear only to suggest rather than imitate chariot wheels and have a simpler design that is perhaps more decorative in the context of late La Tène art.

Archaeometric analysis of large assemblages from the La Tène period revealed the recurrence of a particular material composition of the eight-spoked wheels (Danielisová et al., 2018b), which included a large amount of lead, unusually large amounts of antimony, and increased amounts of arsenic and sometimes silver. It was noteworthy that this chemical composition was found only in these amulets and not in the other types of object. West of Bohemia, however, particularly in Bavaria, antimony bronzes have regularly been recorded and associated with the alloying of fahlore copper (Schwab, 2011; 2014a; 2014b). It was not until we detected the same composition in two bronze rings with a rhombic section, used as a closure mechanism in the context of a Celtic coin hoard from Libčice nad Vltavou (Figures 2 and 3), that the connection with Bavaria became worth considering.

We therefore decided to give more attention to this matter and to investigate the alloy design and provenance of these objects and to explore the broader socio-cultural or political implications. In addition to "official" commercial

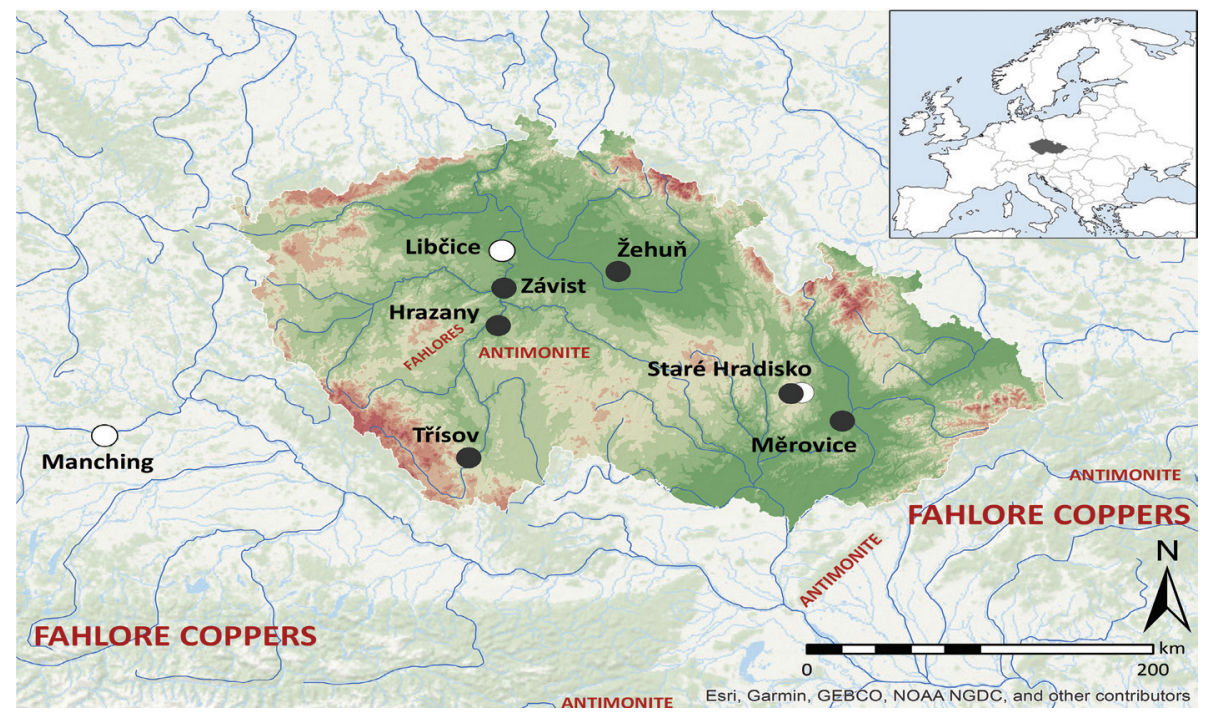

Figure 2. Map of sites mentioned in the text and main deposits of fahlore coppers and antimonites in central Europe. Filled symbols: wheel amulets; hollow symbols: rings with a rhombic section; sites represent coin hoards, oppida, and lowland settlements. 

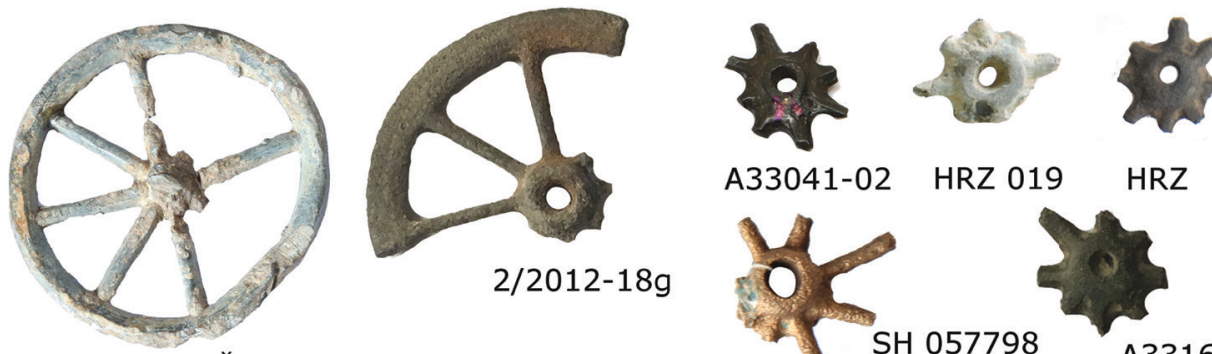

A33041-02 HRZ $019 \quad$ HRZ

MĚ 177.916

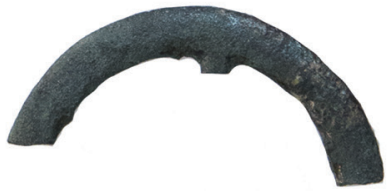

ZAV4
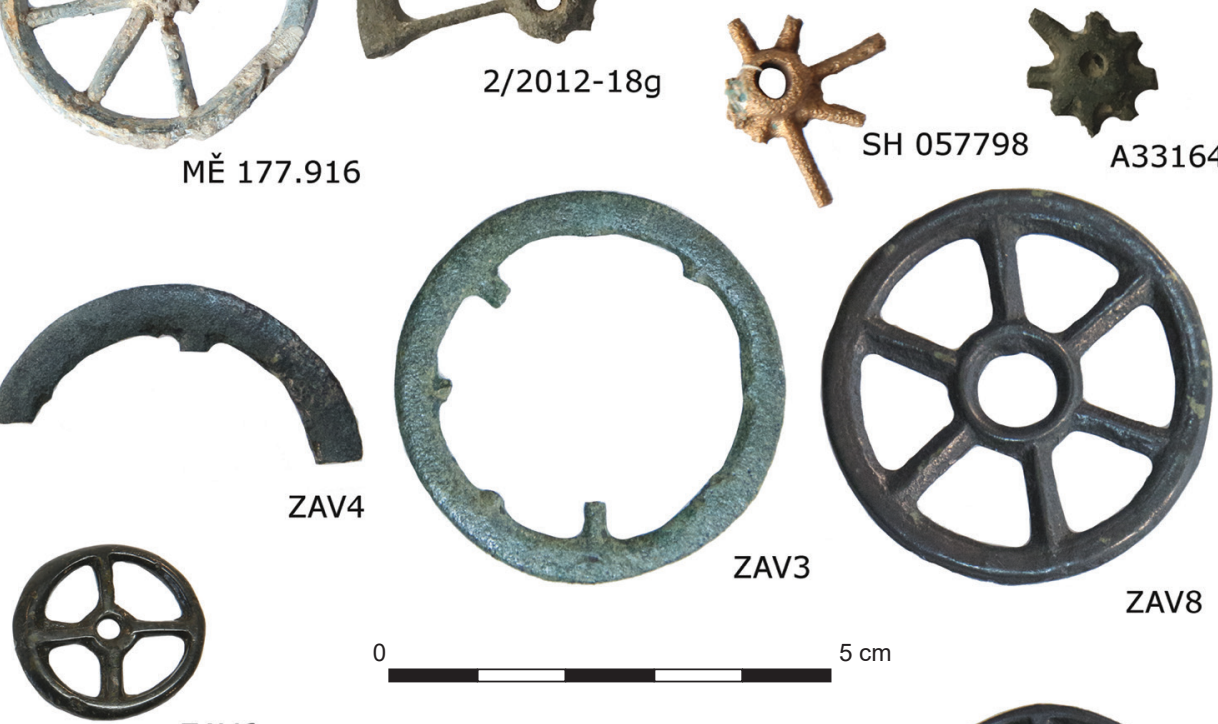

A33164

ZAV6

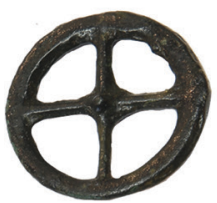

ZAV5

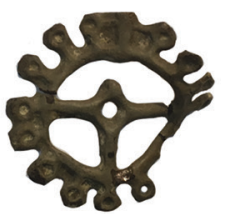

a)

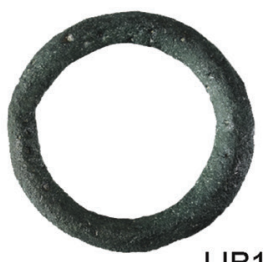

LIB1

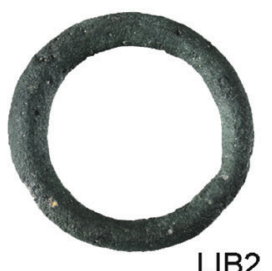

LIB2

b)
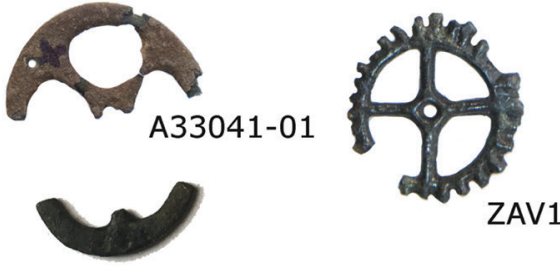

2/2012-22c

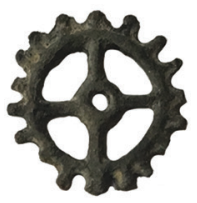

2/2012-2
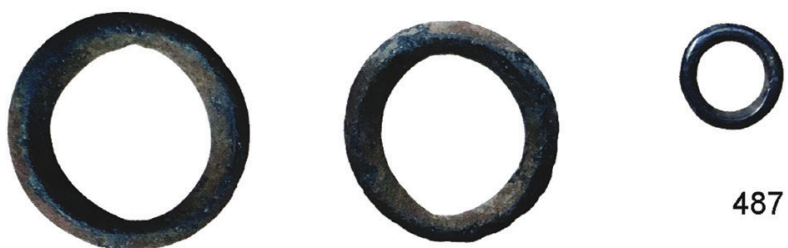

487
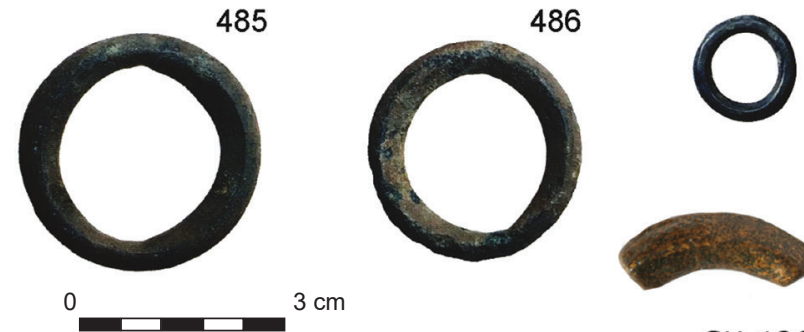

ZAV7
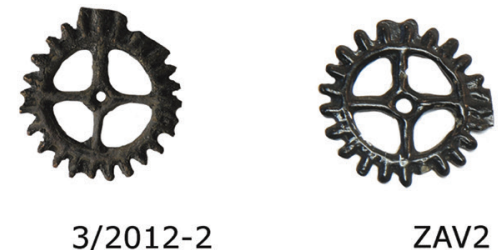

ZAV2 
connections in these areas, which can be seen from the common material culture and the exchange of coins, subtler social mechanisms based on personal mobility or an elusive world of rituals may have also been at play.

\section{Materials and Methods}

We were able to sample a total of 28 eight- and four-spoked bronze ring amulets and rings ( $c f$. Table 1, Figure 3a, 3b), from seven sites (Figure 2), selected from an assemblage of La Tène period objects analysed under a project looking at copper alloys of the later Iron Age. We obtained data on the composition of all 28 objects; further analysis was carried out on 22 of them to determine their lead isotopic signature. Samples were drilled to the metal core in order to avoid the corrosion layers ( $c f$. Lutz and Pernicka, 1996) and to collect the minimum amount of material necessary for analysis.
The objects were small and highly corroded, so the sample weight varied between 0.01 and $0.05 \mathrm{~g}$.

Analysis of the chemical composition and lead isotopes was performed at the Institute of Geochemistry, Mineralogy and Mineral Resources, Charles University, Prague. Mass spectrometry (ICP-MS) and lead isotope analysis (MCICP-MS) were applied in order to determine the chemical composition and possible provenance of the artefacts. The major elements $(\mathrm{Cu}, \mathrm{Sn}, \mathrm{Pb})$ and trace elements $(\mathrm{Sb}, \mathrm{Ag}$, $\mathrm{As}, \mathrm{Zn}, \mathrm{Ni}, \mathrm{Co}, \mathrm{Fe}, \mathrm{Bi}$ ) were determined using modified digestion in mineral acids $\left(\mathrm{HNO}_{3}+\mathrm{HCl}, 3: 1\right)$, followed by conventional solution nebulization ICP-MS iCAPQ (Thermo, Bremen) and/or ICP OES Agilent 5110 (Agilent, USA). Approx. 0.01-0.02 g of each sample was digested in $2.5 \mathrm{ml}$ of the acid mixture $\left(\mathrm{HNO}_{3}+\mathrm{HCl}, 3: 1\right)$ in PTFE vessels (Savillex, USA) on a hot plate $\left(100^{\circ} \mathrm{C}\right.$ for $1-2$ hours) and transferred to a $25 \mathrm{ml}$ volumetric flask. All the samples and procedural blanks were further diluted one thousand-fold

Table 1. List of the analysed objects, their types, and contexts ("4-ray": four-spoked wheel amulets; "8-ray": eight-spoked wheel amulets; "ring": bronze ring with a rhombic section).

\begin{tabular}{|c|c|c|c|c|}
\hline Id. & Inv. number & Site & Context & Type of amulet \\
\hline 1 & ZAV1 & Závist & oppidum & 4-ray \\
\hline 2 & ZAV2 & Závist & oppidum & 4-ray \\
\hline 3 & ZAV5 & Závist & oppidum & 4-ray \\
\hline 4 & ZAV6 & Závist & oppidum & 4-ray \\
\hline 5 & detekt. & Žehuň & settlement & 4-ray \\
\hline 6 & 2/20012-22a & Žehuň & settlement & 4-ray \\
\hline 7 & $2 / 2012-22 b$ & Žehuň & settlement & 4-ray \\
\hline 8 & $2 / 2012-22 c$ & Žehuň & settlement & 4-ray \\
\hline 9 & $2 / 2012-5$ & Žehuň & settlement & 4-ray \\
\hline 10 & $2 / 2012-2$ & Žehuň & settlement & 4-ray \\
\hline 11 & $3 / 2012-2$ & Žehuň & settlement & 4-ray \\
\hline 12 & $2 / 2013-4$ & Žehuň & settlement & 4-ray \\
\hline 13 & A33038 & Trúsov & oppidum & 4-ray \\
\hline 14 & A33041-01 & Třísov & oppidum & 4-ray \\
\hline 15 & A33162 & Třísov & oppidum & 4-ray \\
\hline 16 & ZAV7 & Závist & hallstatt hillfort & 4-ray \\
\hline 17 & ZAV8 & Závist & hallstatt hillfort & 6-ray \\
\hline 18 & ZAV3 & Závist & oppidum & 8-ray \\
\hline 19 & ZAV4 & Závist & oppidum & 8-ray \\
\hline 20 & MĚ 177.916 & Měrovice & settlement & 8-ray \\
\hline 21 & SH 057798 & Staré Hradisko & oppidum & 8-ray \\
\hline 22 & HRZ 019 & Hrazany & oppidum & 8-ray \\
\hline 23 & $2 / 2012-18 \mathrm{~g}$ & Žehuň & settlement & 8-ray \\
\hline 24 & A33041-02 & Třísov & oppidum & 8-ray \\
\hline 25 & A33164 & Třísov & oppidum & 8-ray \\
\hline 26 & LIB1 & Libčice & hoard & ring \\
\hline 27 & LIB2 & Libčice & hoard & ring \\
\hline 28 & SH 136 & Staré Hradisko & oppidum & ring \\
\hline
\end{tabular}




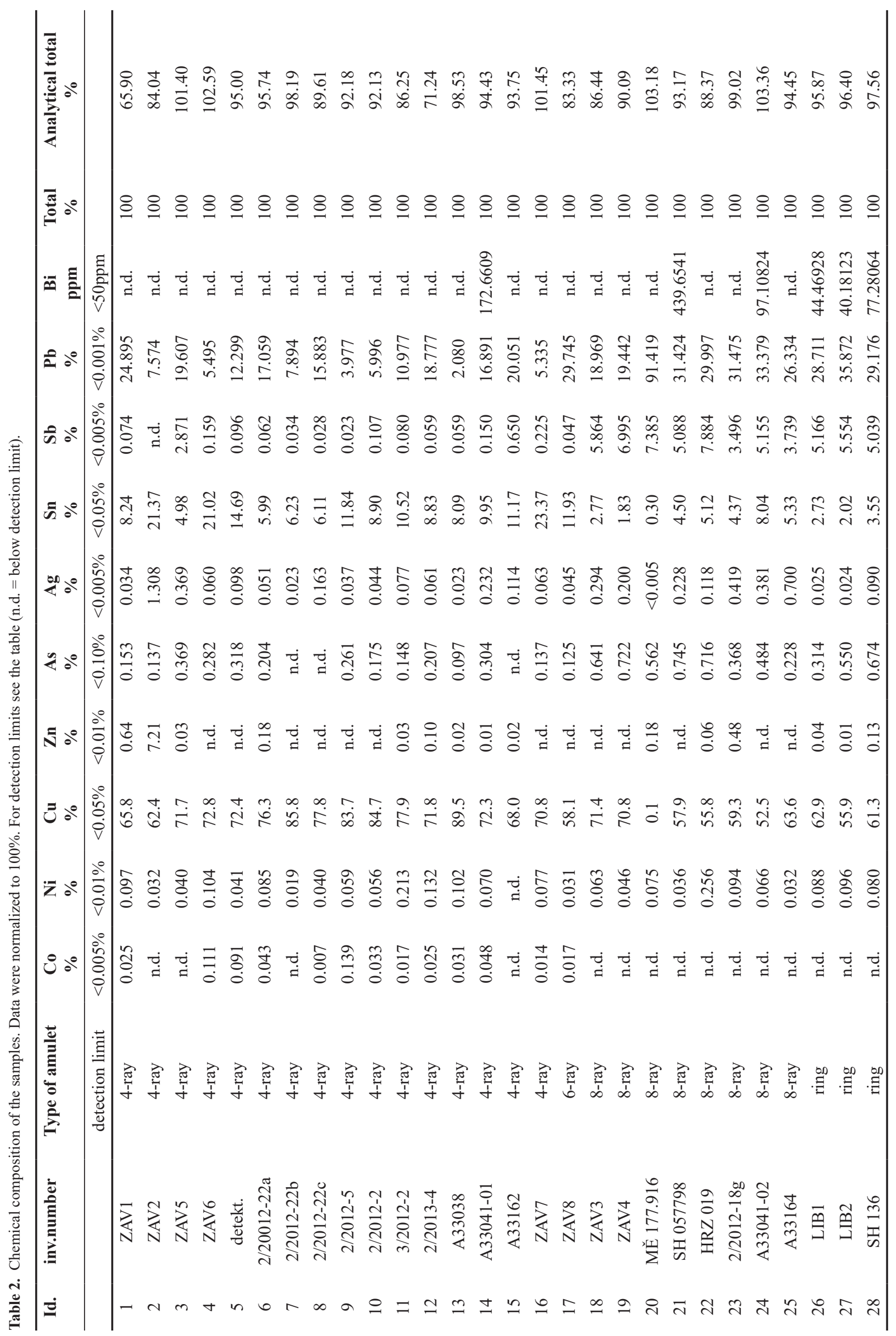


Table 3. Lead isotope data for the wheel amulets and rings with a rhombic section. Data precision (MC-ICP-MS) is better than $0.01 \%$ for ratios with ${ }^{206} \mathrm{~Pb}$ in the denominator and better than $0.03 \%$ with ${ }^{204} \mathrm{~Pb}$ in the denominator.

\begin{tabular}{|c|c|c|c|c|c|c|c|}
\hline Id. & Inv. number & Type of amulet & ${ }^{207} \mathrm{~Pb} /{ }^{206} \mathrm{~Pb}$ & ${ }^{208} \mathrm{~Pb} /{ }^{206} \mathrm{~Pb}$ & ${ }^{206} \mathrm{~Pb} /{ }^{204} \mathrm{~Pb}$ & ${ }^{207} \mathrm{~Pb} /{ }^{204} \mathrm{~Pb}$ & ${ }^{208} \mathrm{~Pb} /{ }^{204} \mathrm{~Pb}$ \\
\hline 1 & ZAV1 & 4-ray & 0.8376 & 2.0842 & 18.711 & 15.672 & 38.998 \\
\hline 2 & ZAV2 & 4-ray & 0.8378 & 2.0847 & 18.707 & 15.673 & 39.000 \\
\hline 3 & ZAV5 & 4-ray & 0.8531 & 2.1005 & 18.364 & 15.667 & 38.573 \\
\hline 4 & ZAV6 & 4-ray & 0.8346 & 2.0672 & 18.779 & 15.674 & 38.821 \\
\hline 5 & detekt. & 4-ray & 0.8373 & 2.0721 & 18.712 & 15.668 & 38.773 \\
\hline 6 & ZAV8 & 4-ray & 0.8377 & 2.0820 & 18.712 & 15.676 & 38.957 \\
\hline 7 & 2/20012-22a & 4-ray & 0.8458 & 2.0824 & 18.467 & 15.619 & 38.456 \\
\hline 8 & $2 / 2012-22 c$ & 4-ray & 0.8411 & 2.0772 & 18.577 & 15.624 & 38.588 \\
\hline 9 & A33162 & 4-ray & 0.8377 & 2.0829 & 18.708 & 15.671 & 38.966 \\
\hline 10 & A33038 & 4-ray & 0.8380 & 2.0823 & 18.702 & 15.670 & 38.943 \\
\hline 11 & A33041-01 & 4-ray & 0.8378 & 2.0828 & 18.708 & 15.673 & 38.964 \\
\hline 12 & ZAV7 & 6-ray & 0.8372 & 2.0828 & 18.722 & 15.674 & 38.995 \\
\hline 13 & ZAV3 & 8-ray & 0.8377 & 2.0845 & 18.711 & 15.675 & 39.003 \\
\hline 14 & ZAV4 & 8-ray & 0.8382 & 2.0849 & 18.702 & 15.676 & 38.991 \\
\hline 15 & MĚ 177.916 & 8-ray & 0.8478 & 2.0842 & 18.405 & 15.604 & 38.360 \\
\hline 16 & SH 057798 & 8-ray & 0.8395 & 2.0847 & 18.675 & 15.677 & 38.932 \\
\hline 17 & $2 / 2012-18 \mathrm{~g}$ & 8-ray & 0.8410 & 2.0866 & 18.630 & 15.669 & 38.873 \\
\hline 18 & A33164 & 8-ray & 0.8392 & 2.0842 & 18.673 & 15.669 & 38.919 \\
\hline 19 & A33041-02 & 8-ray & 0.8386 & 2.0730 & 18.676 & 15.661 & 38.714 \\
\hline 20 & HRZ 019 & 8-ray & 0.8379 & 2.0832 & 18.692 & 15.662 & 38.938 \\
\hline 21 & LIB1 & ring & 0.8379 & 2.0831 & 18.711 & 15.677 & 38.975 \\
\hline 22 & LIB2 & ring & 0.8378 & 2.0830 & 18.713 & 15.678 & 38.980 \\
\hline
\end{tabular}

by $2 \%(\mathrm{v} / \mathrm{v}) \mathrm{HNO}_{3}$ before measurements were taken. All the chemicals used in the dissolution were reagent grade (Merck, Germany) and the acids were double distilled. Deionized water from a Millipore system (Millipore, USA) was used for all dilutions. All solutions were stored in HDPE (Nalgene) bottles. The ICP-QMS analytical protocol and calibration strategy closely followed those described by Strnad et al., 2007 and 2016. The analytical precision of the ICP-MS data for all the analysed elements ranged from $0.3 \%$ to $3 \%$ relative ( $c f$. Table 2 ).

To determine provenance, the samples for lead isotopic analysis were dissolved in $5 \mathrm{ml}$ of aqua regia $\left(1: 1 \mathrm{HNO}_{3}\right.$ and $\mathrm{HCl}$ ). Lead was separated using Sr-spec resin (Triskem) and ultrapure $6 \mathrm{M} \mathrm{HCl}$ (Romil) as elution media. The isotopic analysis was performed using Neptune MC-ICPMS (Thermo-Fisher Scientific). Samples were spiked with thallium reference material NIST SRM 997 and the mass bias was corrected with the generalized power law using $203 \mathrm{Tl} / 205 \mathrm{Tl}=0.418922$ (Košler et al., 2008). The lead isotopic data were corrected using the standard-sample bracketing approach relative to NIST declared values for the SRM 981 reference material. The baseline after wash was each under $0.0004 \mathrm{mV}$. Relative analytical precision of measurements by MC-ICP-MS are better than $0.005 \%$ (RSD) for $206 \mathrm{~Pb} / 207 \mathrm{~Pb}$ and $208 \mathrm{~Pb} / 206 \mathrm{~Pb}$, and better than $0.01 \%$ for $206 \mathrm{~Pb} / 204 \mathrm{~Pb}, 207 \mathrm{~Pb} / 204 \mathrm{~Pb}$ and $208 \mathrm{~Pb} / 204 \mathrm{~Pb}$ (cf. Table 3 ).

\section{Results}

\subsection{Chemical composition - the alloy design}

The ICP-MS analysis shows that the amulets are made of tin bronze that always contained at least $2 \%$ lead (Table 2 ). The alloy design was strongly connected to typology. Figure 4 shows the chemical profiles of the typological groups according to the main alloying components (except copper) and the minor and trace elements. The chemical composition of the four-spoked wheels and the materials used to make them are quite diverse; the chemical composition of the eight-spoked wheels and the rings is largely homogeneous. The small variations in the trace elements could be a result of the different origins of the copper in the alloys (no data on the origin of the copper is available). One significant feature of the eight-spoked wheels is the large amount of lead in the alloy, usually between $20 \%$ and $30 \%$. A similar lead content was observed in the rings found with the coin hoards; one ring from Libčice contained 28\% lead, the other ring 35\%.

Another feature that clearly distinguishes the eight-spoked wheels from the four-spoked wheels is the high antimony content (4-8\%) in the alloy, and higher readings of arsenic (around $0.5 \%$ ) (Figure 5). Where the amount of antimony is higher, the tin content decreases proportionally.

Lead-antimony bronzes are not rare in prehistory (Frána et al., 2009; Schwab, 2011). Higher amounts of antimony 

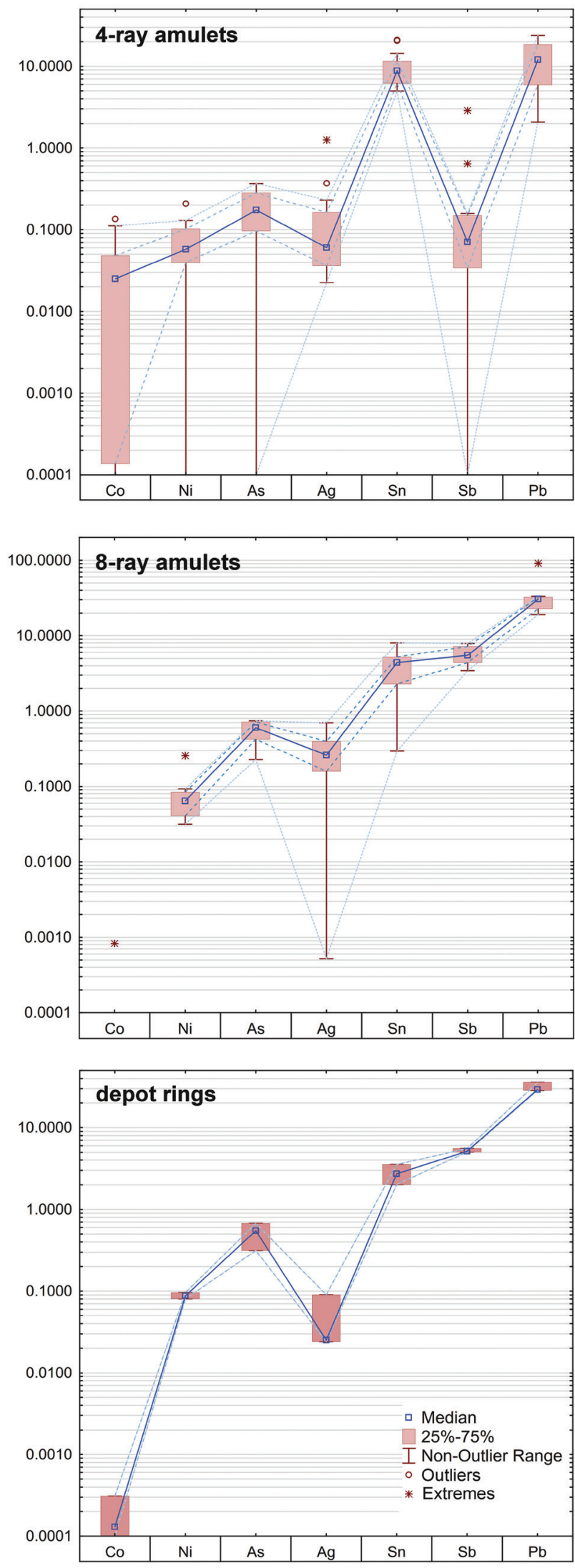

Figure 4. Variability plots of the chemical profiles of the minor and trace elements of the individual types of amulet/ring. The figure shows comparatively larger heterogeneity in the case of four-spoked wheels compared to the uniform designs of the eight-spoked wheels and rings with a rhombic section. Values log-normalized, given in $\%$.

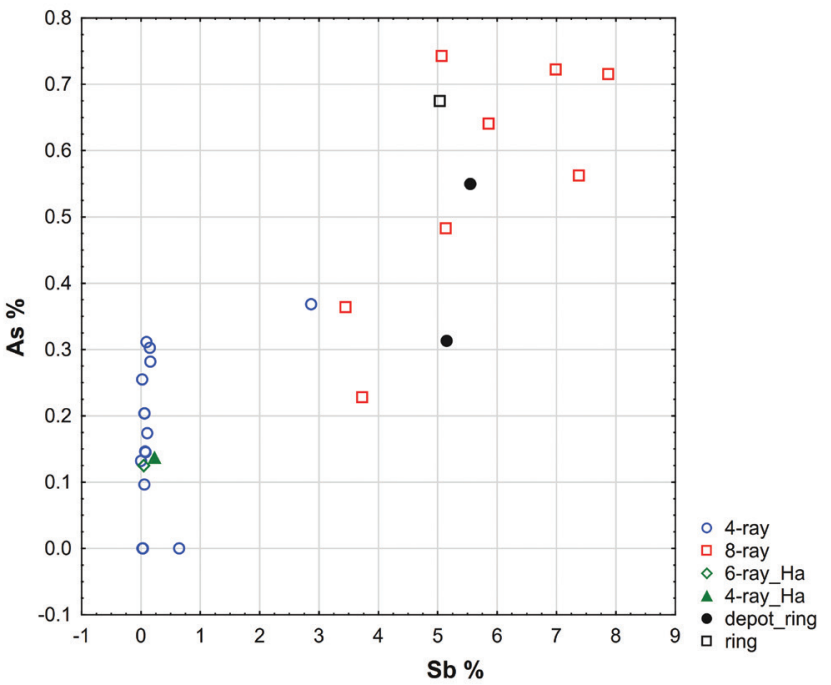

Figure 5. Differences in the alloy composition of the four-spoked and eight-spoked wheel amulets, showing the use of fahlore copper for the fabrication of the latter. Rings with a rhombic section were made from the same material, while the (possibly) Hallstatt period amulets from Závist have the same composition as the four-spoked amulets.

together with other characteristic trace elements (As, Ag, sometimes $\mathrm{Ni}$ ) is attributed to tetrahedrites (commonly referred to as fahlores), a high-impurity copper used widely from the beginning of the Bronze Age (Frána et al., 1997; 2009; Niederschlag et al., 2003; Lutz and Schwab, 2014a; Schwab, 2014b; Nørgaard et al., 2019). In the Czech lands, however, this copper becomes scarce after the early Bronze Age (Frána et al., 1997; 2009).

An almost identical case to that described above is the oppidum of Manching (Figure 3b), where rings of the same shape and dimensions were part of a closure mechanism on a container holding a famous hoard of gold coins discovered in the 1990s (Zieghaus, 2013). The analytical values of the major and trace elements were normalized to $100 \%$, but the proportions of the individual alloy components are basically the same as those in the Libčice hoard. In Bavaria, the appearance of an alloy where antimony appears to replace tin is recorded from LT C2 (i.e. $2^{\text {nd }}$ century $\mathrm{BC}$ ) onwards. The presence of antimony as a regular admixture in late La Tène alloys has been observed in numerous types of objects: wheel amulets, belt fittings, ring beads, mirrors, and small figural works of art (Schwab, 2014b). Further west, the antimony was frequently present in bronze-cast coins, the potins (Burkhardt et al., 1994; Haselgrove, 1999; Schwab, 2014b) which circulated widely in Gaul, Belgium, and Britain. It is interesting that in Bohemia and Moravia this alloy has so far been detected only in amulets and rings which served a particular function.

The eight-spoked amulet from Merrovice (MĚ 177.916), found using a metal detector, was exceptional in being almost completely made of lead (91\%), plus an admixture of antimony (ca. 7\%). Such an alloy is highly unusual, although lead amulets are reported from Germany (Schwab, 2014b). Lead is a soft metal, so antimony could improve 
the mechanical properties, or give an item a more silverlike appearance, but the precise reasons for alloying lead with antimony are unknown. The Merrovice case suggests that antimony could have been added to the alloy as a standalone component and not as part of the fahlore. Antimony is a grey metalloid and ores are recognizable by their silvery appearance. Antimony usually forms its own minerals (e.g. stibnite or pyrargyrite) or can be bound in, for example, an arsenopyrite and/or tetrahedrite structure (e.g. Andráš et al., 2010). The processing of antimonite ores was not demanding from the technological point of view as its melting point is $630.6^{\circ} \mathrm{C}$ (stibnite, the most typical antimony sulphide, has a melting point of $546^{\circ} \mathrm{C}$ ). Antimony mineralization and deposits across central Europe (cf. Figure 2) include western Slovakia and the Low Tatra mountains (Andráš et al., 2010), the Rhineland (Wagner and Schneider, 2002), the eastern Alps, and a significant occurrence in the Massif Central (Négrel et al., 2019). Other minor occurrences include the Erzgebirge area, the central part of the Bohemian Massif, and throughout the Alps. Antimony can also be a by-product of copper and silver mining and non-placer gold exploitation. Antimony (Sb$\mathrm{Au}$ mineralization) was intensively mined near Krásná Hora nad Vltavou in central Bohemia until 1991 (Němec and Zachariáš, 2018). An elite La Tène settlement in the surrounding area included finds of bronze objects (including a four-spoked wheel) containing large amounts of antimony (Bursák et al., forthcoming). It is highly probable that these objects were manufactured on site using local raw materials. Knowledge of the occupation of this region could be key to discovering more about the history of the use of antimonite in late La Tène metallurgy.
Antimony-lead alloys are also typical in commercial applications in modern times. It is used as the cast metal for grids and terminals in lead-acid storage batteries, in which the antimony content can reach $8 \%$, with about $0.25 \%$ tin and small amounts of arsenic, copper, and silver. The Měrovice sample trace element readings are $0.1 \% \mathrm{Cu}, 0.18 \%$ $\mathrm{Zn}, 0.5 \% \mathrm{As}$, and $0.3 \% \mathrm{Sn}$, so a modern origin (despite its authentic appearance) is plausible and the interpretation must be treated with caution. Lead isotopic ratios plot this object as an outlier, but within the linear distribution of other samples and close to the isotopic signature of amulets from Wallendorf (see 3.2, Figure 6).

All the other samples with a significant amount of antimony are typical of fahlores. Apart from typical deposits of fahlore coppers from the Alpine area and Slovakian Ore Mountains (Nørgaard et al., 2019), several tetrahedrite samples were analysed from the Př́bram area in central Bohemia (Frána et al., 2009). This area also bears evidence of late La Tène occupation with tentative attempts to link it to metallurgical activities (Waldhauser et al., 2010).

\subsection{Lead isotopes: Provenance}

The high lead content in the alloys means each depositoriented investigation can only indicate the origin of the added lead. The lead content obscures the $\mathrm{Pb}$ isotope signature of the copper in the alloy and thus only the source of the galena can be traced. In the case of recycling, that is, the addition of another lead source, a mixture of the lead added to the new alloy is produced. Both phenomena can be observed in this assemblage (Figure 6).

Unfortunately, a solid corpus of comparative data for the Iron Age is still lacking. Questions of provenance are very

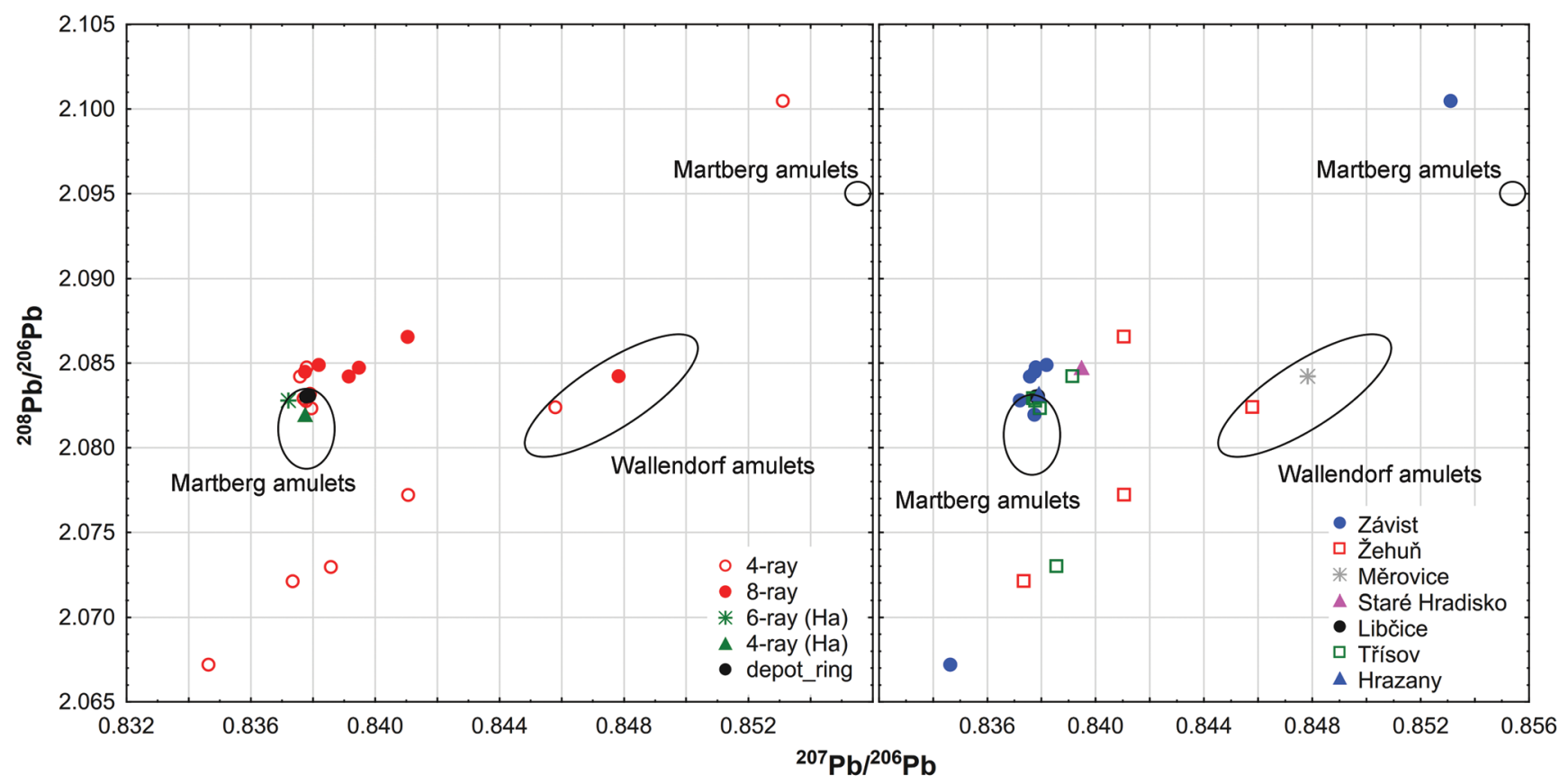

Figure 6. Lead isotopic ratios of the amulets with analysed analogies from Germany (after Schwab, 2014b). The data show the homogeneity of the lead in the eight-spoked wheels compared to the four-spoked wheels which visibly scatter along the line below, which suggests a mixing of sources within different deposits. 
Figure 7. Lead isotopic ratios of the amulets projected against known deposits in Germany, Bohemia, Spain, and the Alps. The values do not show an exact match with any of the deposits, but rather suggest a mixing of the Spanish lead with other sources in the case of the eight-spoked wheels, some of the four-spoked wheels, and both of the rings from Libčice. The four-spoked wheels are on the mixing line below and suggest local sources, possibly from the German Mittelgebirge area and the Erzgebirge. Background data from: Bielicki and Tischendorf, 1991; Bode, 2008; Brauns, 1995; Durali-Müller, 2005; Krahn and Baumann, 1996; Lehman, 2011; Leveque and Haack, 1993; Niederschlag et al., 2003; Durali-Müller et al., 2007; Tischendorf et al., 1992; Zwicker et al., 1991; Legierski and Vaněček, 1967; Cattin et al., 2011; Pernicka et al., 2016; Höppner et al., 2005; Artioli et al., 2016; OXALID; Arribas and Tosdal, 1994; Domerque et al., 2012; HuntOrtiz, 2003; Klein et al., 2007; Klein et al., 2009; Marcoux et al., 1992; Stos-Gale et al., 1995; Santos Zalduegui et al., 2004; Tornos and Chiaradia, 2004; Trincherini et al., 2001; Trincherini et al., 2009; Velasco et al., 1996.
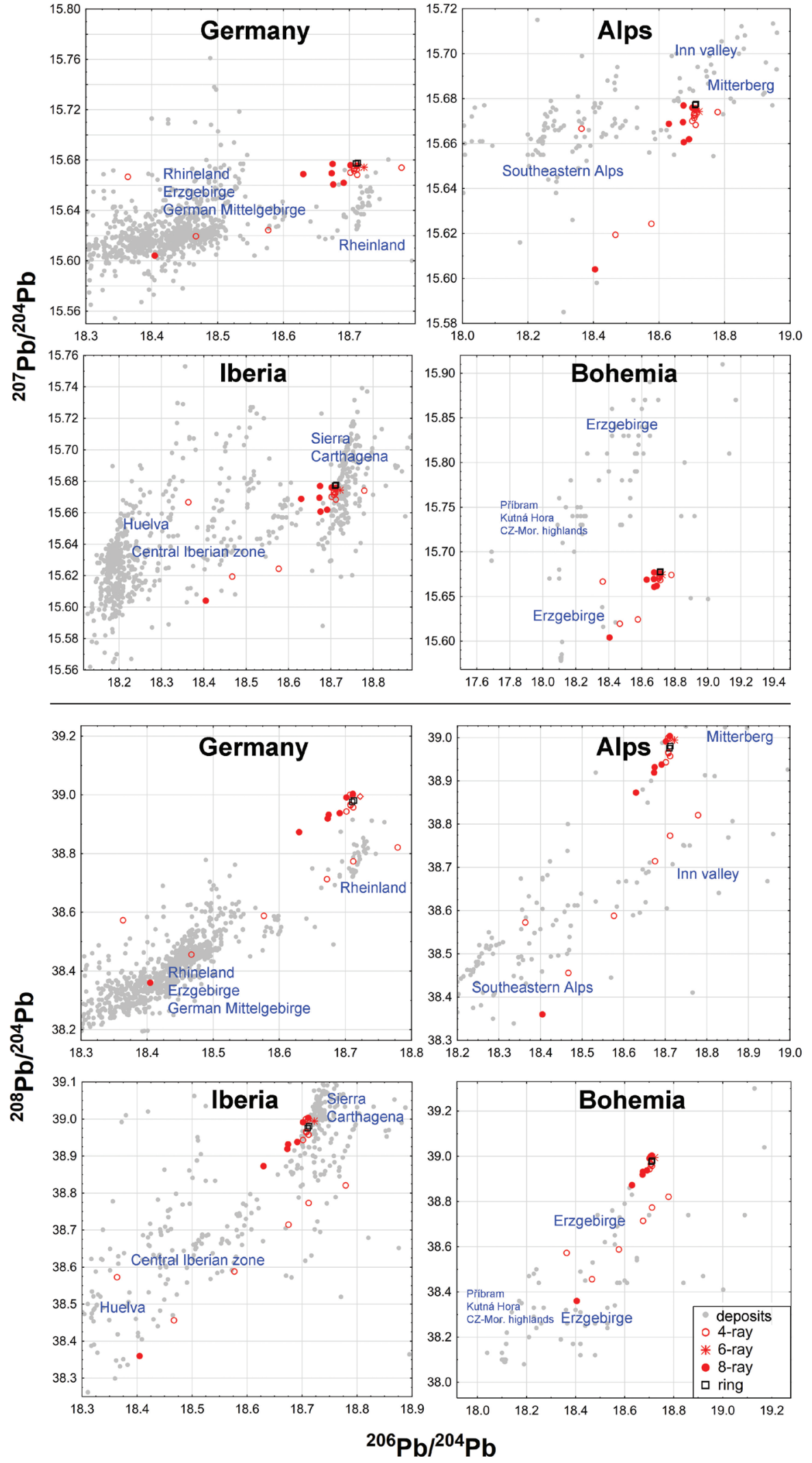

difficult to answer as large mining areas in Europe, such as Mitterberg, had already served their time and were replaced by numerous smaller areas, whose importance for the Iron Age is yet to be adequately assessed (Schwab, 2014b).
Because the amulets were found at settlements with proven connections with other regions, such as Spain, and because of the availability of existing research ( $c f$. Danielisová et al., 2018b; Schwab, 2014b), comparison was made with known 
deposits in the Czech Republic, the German Mittelgebirge zone (central and southern Germany), the Alps, and Iberia.

From the distribution of the lead isotope ratios, we can make the following observations:

1) The $\mathrm{Pb}$ ratios of eight-spoked wheels and rings with a rhombic section are very homogeneous and confirm the results of the chemical composition analysis. Both of the amulets from Závist, dated to the Hallstatt period (ZAV7, ZAV8) plot in this group, which suggests a later dating. The four-spoked wheels scatter along the line below the first group, which suggests a mixing of sources within different deposits (Figure 6).

2) $\mathrm{The} \mathrm{Pb}$ ratios are also quite consistent with the origin of the amulets. The eight-spoked wheels from Závist, Staré Hradisko and Trrísov have similar ratios to the amulets from Martberg (Schwab, 2014b). This suggests a super-regional system which has already been postulated for the late Iron Age supply of metal to the oppida (Danielisová et al., 2018b). The fourspoked wheels plot within the trend of the amulets from Wallendorf, for which a mixing of local (i.e. German or Bohemian) sources of lead has been suggested (Schwab, 2014b). The Variscan deposits in the Rhineland, German Mittelgebirge zone or the Erzgebirge (which connect the German and Bohemian objects) can also be considered.

3) The eight-spoked wheels do not greatly overlap any of the predicted deposits (Figure 7). The data show that they are closest to the deposits in southeast Spain (Sierra Cartagena, Murcia, Alméria), but not close enough for $100 \%$ certainty. The same observation was made with the amulets from Martberg, where a mix of various Spanish lead sources was suggested (Schwab, $2014 \mathrm{~b})$. The $\mathrm{Pb}$ ratios of the four-spoked wheels, on the other hand, do not seem to be a result of mixing Spanish lead with local geologically older deposits as was suggested for Germany (Schwab, 2014b).

\section{Discussion}

The use of a high-impurity copper for the production of particular objects, in this case eight-spoked wheel amulets and rings with a rhombic section, may or may not have been a result of requirements for a specific alloy design. It has been suggested that the alloy was designed for the resulting colour: leaded bronze is usually a golden-yellowish colour (Devogelaere, 2017); adding antimony would yield a more silver-like appearance (Schwab, 2014a). Fahlore copper with arsenic and antimony has similar properties to tin-rich bronzes: arsenic and antimony can replace part of the tin in the $\delta$ eutectoid or form their own intermetallic phases such as $\mathrm{Cu}_{4} \mathrm{Sb}$ and $\mathrm{Cu}_{3} \mathrm{As}$. Experiments have shown that the colour spectrum of these alloys is red-brown to gold depending on the antimony and tin content, but that the surfaces are silvercoloured in all cases as a result of inverse ingot segregation after casting (Schwab, 2014b). The alloy composition does not have ideal mechanical properties (Northover, 2004), which is perhaps why it was used only for smaller decorative objects such as rings, belts, beads and mirrors, and the amulets (Schwab, 2014a). Schwab (2014a) has also suggested that antimony replaced tin in the more expensive alloys - used for mirrors and bronze potin coins - to produce an imitation of silver or a high-tin bronze called speculum.

It is yet to be established whether the fahlore copper and antimonite were used because of a shortage of tin caused by the repeated recycling of objects, a scarcity of raw materials caused by disruption to the supply, as has been suggested for Bavaria (Schwab, 2014a), or because minerals were available which gave the alloys the desired visual properties. The items from Bohemia show that antimony did not replace tin entirely, but formed another component of the alloy. Evidence of antimony in copper-free objects (Merrovice) and in the area bearing antimony deposits (the region around Krásná Hora nad Vltavou) may also suggest the use of antimony minerals as standalone components, although evidence of the use of fahlores also exists.

The common occurrence of antimony bronzes at Manching (Schwab, 2014a), where the antimony content reaches as high as $10 \%$, suggests that it is an intentional alloy. The use of fahlores in Bavaria is seen as evidence of the widespread smelting of local ores from deposits in the Alps and the German Mittelgebirge zone as fahlores are not observed in the analysis of Mediterranean alloys from the same period (Schwab, 2014b). However, in Bohemia, fahlores were not used past the Bronze Age (Niederschlag et al., 2003; Frána et al., 1997; 2009; Danielisová et al., in print). For this reason, it becomes significant that (with exceptions, $c f .3 .1$ ) no objects in Bohemia apart from the eight-spoked wheels and the rings found with the coin hoards were made using fahlores. This naturally raises the question as to whether this phenomenon is a result of deliberate alloying reserved for particular objects or is a matter of provenance. The latter would lead us to expect the movement of amulets and rings (bound to their owners or in the form of raw material) with the fahlore signature from Bavaria to sites in Bohemia and Moravia. Local production would thus become pointless, but the great spread of amulets across different social groups (oppida and the countryside) would suggest either a high level of mobility or the need to reconsider the possibility of local production. When comparing mutual ratios of the selected elements (Figure 8), which show two different rates of depletion of $\mathrm{As}$ and $\mathrm{Sb}$ relative to $\mathrm{Ag}$, it is clear that it is not the typology but the site that is consistent with the pattern of trace elements. This suggests that the amulets were not produced at a single location, but that at each different site the alloy design particular to each product was always maintained. It may also suggest that each major settlement had its own network of contacts who brought amulets in from particular production sites (the clearest division is that between Závist and Třísov oppida). Site specificity also appears distinctive with respect to $\mathrm{Pb}$ isotope ratios (Figure 6).

The rings bearing a rhombic section are similar to the eight-spoked amulets in both chemical composition and $\mathrm{Pb}$ 


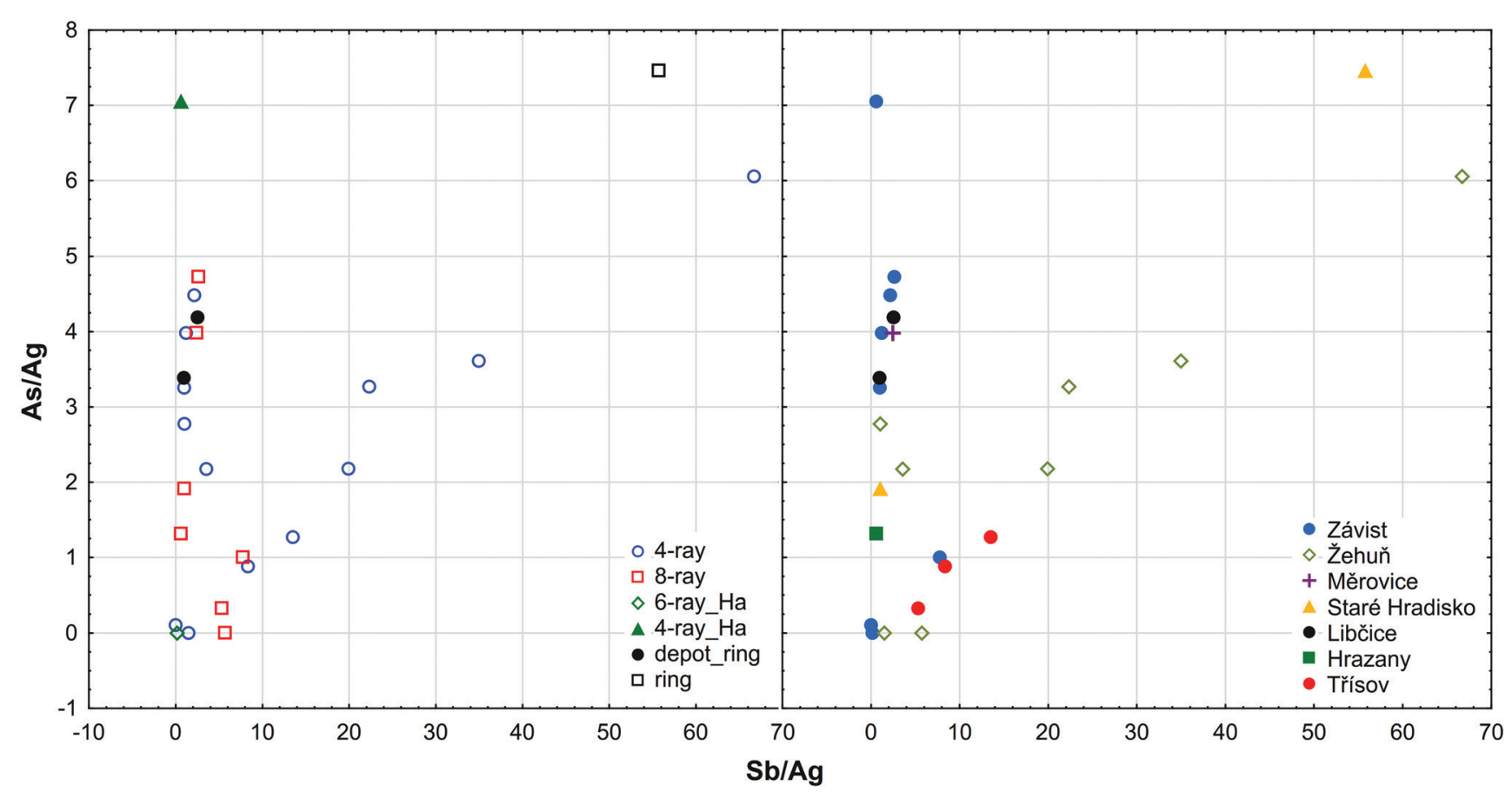

Figure 8. The common denominator $(\mathrm{Ag})$ of the $\mathrm{x}$-axis and $\mathrm{y}$-axis gives rise to a dual linear trajectory showing two trends in the chemical composition. These trends are dependent not on the type of amulet but on the site. This suggests that individual settlements might have been involved in producing their own amulets using different kinds of copper but following the required alloy design. The two linear trajectories could also suggest binary mixing of (yet) unknown end-members.

isotopes (Figure 3b). Such rings were often used as closure systems on organic containers holding coin hoards. A similar bronze ring was found in a depot at Lauterach in the Vorarlberg (Pauli, 1991) and two bronze rings are also reported in the context of the Starý Kolín coin hoard in Bohemia (Militký, 2018). Regarding provenance, it may be significant that coins found in the Libčice hoard were of Thuringian and Bavarian origin, which could explain the use of fahlore copper to make the closure rings. A similar explanation can be suggested in the case of Lauterach, not far from Bavaria, in an area of Alpine deposits that also contained fahlores. The Starý Kolín hoard on the other hand contained only coins of local, i.e. Boian, origin. The composition of the bronze rings from Lauterach and Starý Kolín is unknown. The numerous rings with a rhombic section from Manching (van Endert, 1991) and Staré Hradisko (SH 136) may suggest that the rings were produced at the oppida and were a typical part of the local material culture. Those found with the coin hoards are the only rings whose chemical composition was analysed. The fact that exactly the same alloy was used for the rings and the amulets also suggests that not only the type and shape of an object but also the processes used in its manufacture played a significant role in the ritual life of the late Iron Age.

\section{Conclusion}

Spoked-wheel amulets are an interesting aspect of the material culture of the middle and especially the late La Tène period. They were used as personal jewellery, possibly with a specific function as a symbol of the Sun. There were various designs, but two basic types prevailed: fourspoked wheels (with numerous sub-variations) and eightspoked wheels (with few or no variations). It was the latter group that proved interesting with respect to archaeometric analysis and this was because of their specific alloy design. The elevated concentrations of arsenic, silver and especially antimony led to the conclusion that they were made using fahlore copper. The use of fahlores is almost unknown in Iron Age Bohemia and Moravia but common in Germany (the oppida of Manching and Martberg specifically), where it was used for amulets and other items, perhaps where a silvery appearance was required. Interestingly, the only objects for which the use of fahlore copper was detected in Bohemia were these particular types of amulet. More interesting still was the discovery of the same composition in the bronze rings that served as a closing mechanism for sacks containing coin hoards. This all naturally gave rise to questions about the provenance and origin of this alloy design, which according to the lead isotopes is also highly homogeneous. The lead used in the eight-spoked wheels and the closure rings has a common source. It was possibly a mixture of Spanish lead brought to the Transalpine areas as part of the extensive trade in metals which probably involved most of the oppida and other major sites in central Europe (cf. Danielisová et al., 2018b; Schwab, 2014b).

The eight-spoked wheels and the rings with a rhombic section may be part of a well-organized production system as they feature Spanish lead but were made locally using fahlore copper (and perhaps antimonite). The reasons 
behind the choice of materials might have been: (a) purely practical (the availability of raw materials at a specific location); (b) aesthetic (the silvery appearance of the alloy); (c) technological (better workability); or even (d) symbolic (the exact number and ratios of the individual components).

We can create a picture of the wearers of these amulets, who travelled from the oppida in the western part of central Europe where Spanish lead and fahlore copper were routinely processed. We can also draw a picture of the special materials being imported to the places of production based on the particular demands of the alloy design. Last, but not least, we can envision locally exploited fahlores and antimonites being processed. All three hypotheses are equally plausible but (perhaps excepting the last of the three) lack direct supportive evidence.

Unlike the eight-spoked wheel amulets, the four-spoked wheels show great diversity in their chemical composition and lead isotopes, and these are mostly compatible with their places of origin, thus reflecting local production. It appears that no particular rules were followed when producing these objects. It is perhaps safe to say that unlike the eight-spoked wheels, the four-spoked wheels, which are similar in their symbolism but more "free-hand" in their execution, were a true part of the late La Tène "pop culture".

\section{Acknowledgments}

This work was supported by the Czech Science Foundation [project: "Mobility of materials and life cycles of artefacts: archaeometry of metals and glass of the La Tène and Early Roman period"; project number: 18-20096S].

\section{References}

ANDRÁŠ, P., CHOVAN, M., DIRNER, V., KRÁL', J., BACHLINSKI, R., 2010. Pb-isotope study in Sb-mineralisation from Western Carpathian (Slovakia). Carpathian Journal of Earth and Environmental Sciences, 5(2), 71-80.

ARRIBAS, A., TOSDAL, R., 1994. Isotopic composition of $\mathrm{Pb}$ in ore deposits of the Betic Cordillera, Spain; origin and relationship to other European deposits. Economic Geology, 89(5), 1074-1093.

ARTIOLI, G., ANGELINI, I., NIMIS, P., VILLA, I., 2016. A lead-isotope database of copper ores from the Southeastern Alps: A tool for the investigation of prehistoric copper metallurgy. Journal of Archaeological Science, 75, 27-39.

BIELICKI, K., TISCHENDORF, G., 1991. Lead isotope and $\mathrm{Pb}-\mathrm{Pb}$ model age determinations of ores from Central Europe and their metallogenetic interpretation. Contributions to Mineralogy and Petrology, 106, 440-461.

BODE, M., 2008. Archäometallurgische Untersuchungen zur Blei-/ Silbergewinnung im Germanien der frühen Römischen Kaiserzeit. Unpublished thesis ( $\mathrm{PhD}$ ), Westfälischen Wilhelms-Universität, Münster.

BRAUNS, C., 1995. Isotopen untersuchungen an Erzen des Siegerlandes. Unpublished thesis $(\mathrm{PhD})$, University of Gießen.

BURKHARDT, A., STERN, W., HELMIG, G., 1994. Keltische Münzen aus Basel: numismatische Untersuchungen und Metallanalysen. Antiqua, 25, Basel: Schweizerische Gesellschaft für Ur- und Frühgeschichte.

BURSÁK, D., JOHN, J., KORENÝ, R., MÍČEK, F., forthcoming. Podmoky (okr. Př́bram) - nová laténská viereckschanze? Archeologie v jižních Čechách.

CATTIN, F., GUÉNETTE-BECK, B., CURDY, P., MEISSER, N.,
ANSERMET, S., HOFMANN, B., KÜNDIG, R., HUBERT, V., WÖRLE, M., HAMETNER, K., GÜNTHER, D., WICHSER, A., ULRICH, A., VILLA, I., BESSE, M., 2011. Provenance of Early Bronze Age metal artefacts in Western Switzerland using elemental and lead isotopic compositions and their possible relation with copper minerals of the nearby Valais. Journal of Archaeological Science, 38, 1221-1233.

ČIŽMÁ ǨOVÁ, H., 2014. Ein Beitrag zu neuen Funden latènezeitlicher gegliederter Rädchen in Mähren. In: J. Čižmářová, N. Venclová, G. Březinová, eds. Moravské křižovatky. Středni Podunaji mezi pravěkem a historii. Brno: Moravské zemské muzeum, pp. 655-666.

DANIELISOVÁ, A., BURSÁK, D., STRNAD, L., TRUBAČ, J., in print. Life cycles of metals in the Iron Age $\left(4^{\text {th }}-1^{\text {st }}\right.$ Century BC). Sourcing and recycling of copper-based alloys. In: Proceedings of $5^{\text {th }}$ International Conference Archaeometallurgy in Europe. Monographies Instrumentum.

DANIELISOVÁ, A., KYSELA, J., MANGEL, T., KYSELÝ, R., MILITKÝ, J., 2018a. Iron Age site in Žehuň, Central Bohemia. An open settlement with central functions. Památky archeologické, 109, 127-178.

DANIELISOVÁ, A., STRNAD, L., MIHALJEVIČ, M., 2018b. Circulation patterns of copper-based alloys in the Late Iron Age oppidum of Tř́sov in Central Europe. Metalla, 24(1), 5-18.

DÉCHELETTE, J., 1914. Manuel d'archéologie préhistorique, celtique et gallo-romain. II. Archéologie celtique ou proto-historique. III partie: Second Âge du Fer ou époque de la Tène. Paris.

DEVOGELAERE, J., 2017. The colour palette of antique bronzes: An experimental archaeology project. Experimental Archaeology, 2017(2). https://exarc.net/ark:/88735/10289 (visited February $9^{\text {th }}, 2020$ ).

DOMERGUE, C., QUARATI, P., NESTA, A., OBEJERO, G., TRINCHERINI, P., 2012. Les isotopes du plomb et l'identification des lingots de plomb romains des mines de Sierra Morena. Questions de méthode: l'exemple des lingots de l'épave Cabrera 4. Pallas, 90, 243256.

DURALI-MÜLLER, S., 2005. Roman lead and copper mining in Germany. Their origin and development through time, deduced from lead and copper isotope provenance studies. Unpublished thesis $(\mathrm{PhD})$, Johann Wolfgang Goethe-Universität, Frankfurt am Main.

DURALI-MÜLLER, S., BREY, G., WIGG-WOLF, D., LAHAYE, Y., 2007. Roman lead mining in Germany: Its origin and development through time deduced from lead isotope provenance studies. Journal of Archaeological Science, 34, 1555-1567.

Van ENDERT, D., 1991. Die Bronzefunde aus dem Oppidum von Manching. Die Ausgrabungen in Manching, Band 13. Stuttgart.

FRÁNA, J., JIRÁŇ, L., MOUCHA, V., SANKOT, P., 1997. Artifacts of copper and copper alloys in prehistoric Bohemia from the viewpoint of analyses of element composition II. Památky archeologické Supplementum, 8, Prague: Institute of Archaeology.

FRÁNA, J., CHVOJKA, O., FIKERLE, M., 2009. Analýzy obsahu chemických prvků nových depotů surové mědi z jižních Čech. Př́spěvek $\mathrm{k}$ metalurgii starší doby bronzové. Chemical composition analyses of new raw copper hoards from South Bohemia. A contribution to the metallurgy of the Early Bronze Age. Památky archeologické, 100, 91-118.

GREEN, M., 1984. The wheel as a cult-symbol in the Romano-Celtic World. Latomus Revue D'Etudes Latines, Bruxelles.

GREEN, M., 1986. The Gods of the Celts. Sutton: Stroud.

HASELGROVE, C., 1999. The development of Iron Age coinage in Belgic Gaul. The Numismatic Chronicle, 159, 111-168.

HECHT, J., JUD, P., SPICHTIG, N., 1991. Der südliche Oberrhein in spätkeltischer Zeit. Beispiel einer frühgeschichtlichen Region. Archäologie der Schweiz, 14(1), 98-114.

HÖPPNER, B., BARTELHEIM, M., HUIJSMANS, M., KRAUSS, R., MARTINEK, K.-P., PERNICKA, E., SCHWAB, R., 2005. Prehistoric copper production in the Inn valley (Austria), and the earliest copper in Central Europe. Archaeometry, 47, 293-315.

HUNT-ORTIZ, M., 2003. Prehistoric mining and metallurgy in South West Iberian Peninsula. Oxford: Archaeopress.

KLEIN, S., RICO, C., LAHAYE, Y., VON KAENEL, H., DOMERGUE, C., BREY, G., 2007. Copper ingots from the western Mediterranean Sea: Chemical characterisation and provenance studies through lead and copper isotope analyses. Journal of Roman Archaeology, 20, 203-221.

KLEIN, S., DOMERGUE, C., LAHAYE, Y., BREY, G., VON KAENEL, G., 2009. The lead and copper isotopic composition of copper ores from the Sierra Morena (Spain). Journal of Iberian Geology, 35(1), 59-68. 
KOŠLER, J., FORST, L., SLAMA, J., 2008. LAMDATE and LAMTOOL: spreadsheet-based data reduction for LA-ICP-MS. In: P. Sylvester, ed. Laser Ablation ICP-MS in the Earth Sciences: Current Practices and Outstanding Issues; Short Course Delivered in Association with Goldschmidt 2008, Vancouver, B.C., 19-20 July, 2008, Short Course Series / Mineralogical Association of Canada. Québec: Mineralogical Association of Canada, pp. 315-317.

KRAHN, L., BAUMANN, A., 1996. Lead isotope systematics of epigenetic lead-zinc mineralization in the western part of the Rheinisches Schiefergebirge, Germany. Mineralium Deposita, 31, 225-237.

KYSELA, J., VENCLOVÁ, N., 2018. Duchovní svět Keltů. In: J. Militký, J. Kysela, M. Tisucká, eds. Keltové. Čechy v 8. až 1. století před Kristem, Praha: Národní muzeum, pp. 125-140.

LEHMANN, R., 2011. Archäometallurgie von mittelalterlichen deutschen Silberbarren und Münzen. Unpublished thesis $(\mathrm{PhD})$, Leibniz Universität, Hannover.

LEGIERSKI, J., VANĚČEK, M., 1967. Lead isotopic composition of some galenas from the Bohemian massif. Acta Universitatis Caroliane - Geologica, 2, 153-172.

LÉVÊQUE, J., HAACK, U., 1993. Pb isotopes of hydrothermal ores in the Harz, in: P. Möller, V. Lüders, eds. Formation of hydrothermal vein deposits - a case study of the Pb-Zn, barite and fluorite deposits of the Harz Mountains. Monogr. Ser. Mineral Deposit, 30, pp. 197-210.

LUTZ, J., PERNICKA, E., 1996. Energy dispersive X-ray fluorescence analysis of ancient copper alloys: Empirical values for precision and accuracy. Archaeometry, 38(2), 313-323.

LUTZ, J., SCHWAB, R., 2014. The Early Iron Age hoard from Fliess in Tyrol and ore resources in the Eastern Alps. In: E. Pernicka, R. Schwab, eds. Under the Volcano. Proceedings of the International Symposium on the Metallurgy of the European Iron Age (SMEIA) held in Mannheim, Germany, 20-22 April 2010. Espelkamp: Verlag Marie Leidorf, pp. 25-34

MARCOUX, E., LEISTEL, J., SOBOL, F., MILESI, J.-P., LESCUYER, J.-L., LECA, X., 1992. Signature isotopique du plomb des amas sulfurés de la province de Huelva, Espagne. Conséquences métallogéniques et géodynamiques, Comptes rendus de l'Académie des sciences. Série 2, Mécanique, Physique, Chimie, Sciences de l'univers. Sciences de la Terre, 314, 1469-1476.

MILITKÝ, J., 2018. Mince jako univerzální prostředek směny. In: J. Militký, J. Kysela, M. Tisucká, eds. Keltové. Čechy v 8. až 1. století před Kristem, Praha: Národní muzeum, pp. 260-279.

NÉGREL, P., LADENBERGER, A., REIMANN, C., BIRKE, M., DEMETRIADES, A., SADEGHI, M., The GEMAS Project Team 1, 2019 GEMAS: Geochemical background and mineral potential of emerging tech-critical elements in Europe revealed from low-sampling density geochemical mapping. Applied Geochemistry, 111, article 104425.

NEMEC, M., ZACHARIÁŠ, J., 2018. The Krásná Hora, Milešov, and Př́ícovy Sb-Au ore deposits, Bohemian Massif: mineralogy, fluid inclusions, and stable isotope constraints on the deposit formation. Mineralium Deposita, 53, 225-244

NIEDERSCHLAG, E., PERNICKA, E., SEIFERT, T., BARTELHEIM, M., 2003. The determination of lead isotope ratios by multiple collector ICPMS: a case study of Early Bronze Age artefacts and their possible relation with ore deposits of the Erzgebirge. Archaeometry, 45, 61-100.

NØRGAARD, H., PERNICKA, E., VANDKILDE, H., 2019. On the trail of Scandinavia's early metallurgy: Provenance, transfer and mixing. PLoS ONE, 14(7): e0219574.

NORTHOVER, J., 2004. Interdisziplinare Untersuchungen zu den Metallfunden. In: I. Bauer, B. Ruckstuhl, J. Speck, eds. Die spätbronzezeitlichen Ufersiedlungen von Zug-Sumpf 3/ 1. Die Funde der Grabungen 1923-37. Zug: Kantonales Museum für Urgeschichte Zug, pp. 102-143.

OXALID. Oxford archaeological lead isotope database from the Isotrace laboratory. http://oxalid.arch.ox.ac.uk/ (visited May 22 $2^{\text {nd }}, 2018$ ).

PAULI, L., 1991. Heilige Plätze und Opferbräuche bei den Helvetiern und ihren Nachbarn. Archäologie der Schweiz, 14(1), 124-135.

PERNICKA, E., LUTZ, J., STÖLLNER, T., 2016. Bronze Age copper produced at Mitterberg, Austria, and its distribution. Archaeologica Austriaca, 100, 19-55.

PÍČ, J., 1903. Čechy na úsvitě dějin. Svazek 2. Hradiště u Stradonic jako historické Marobudum. Starožitnosti země České, 2, Prague.

SANTOS ZALDUEGUI, J., GARCÍA DE MADINABEITIA, S., GIL IBARGUCHI, J., PALERO, F., 2004. A lead isotope database: The Los
Pedroches - Alcudia Area (Spain); implications for archaeometallurgical connections across southwestern and southeastern Iberia. Archaeometry, $46(4), 625-634$

SCHWAB, R., 2011. Kupferlegierungen und Kupferverarbeitung im Oppidum auf dem Martberg, Berichte zur Archäologie an Mittelrhein und Mosel, 17, 267-285.

SCHWAB, R., 2014a. Resources and recycling: Copper alloys and nonferrous metalworking in the oppidum of Manching (Germany). In: E. Pernicka, R. Schwab, eds. Under the Volcano. Proceedings of the International Symposium on the Metallurgy of the European Iron Age (SMEIA) held in Mannheim, Germany, 20-22 April 2010. Espelkamp: Verlag Marie Leidorf, pp. 175-188.

SCHWAB, R., 2014b. Eisenzeitliche Kupferlegierungen und Kupferverarbeitung zwischen Alpen und Eifel. In: S. Hornung, ed. Produktion-Distribution - Ökonomie. Siedlungs- und Wirtschaftsmuster der Latènezeit, Akten des internationalen Kolloquiums in Otzenhausen, 28.-30. Oktober 2011, Universitätsforschungen zur prähistorischen Archäologie, 248, Bonn, pp. 149-162.

STOS-GALE, Z., GALE, N., HOUGHTON, J., SPEAKMAN, R., 1995. Lead isotopic data from the Isotrace laboratory, Oxford: Archaeometry data base 1, ores from the Western Mediterranean. Archaeometry, 37(2), $407-415$.

STÖCKLI, W., 1975. Chronologie der jüngeren Eisenzeit im Tessin. Basel: Schweizerische Gesellschaft für Ur- und Frühgeschichte.

TISCHENDORF, G., FÖRSTER, H., BIELICKI, H., HAASE, G., BANKWITZ, P., KRAMER, W., 1992. On the origin of Hercynian magmatites and ore deposits in the Erzgebirge: Crustal signatures. Zentralblatt für Geologie und Paläontologie, 1(2), 131-146.

TORNOS, F., CHIARADIA, M., 2004. Plumbotectonic evolution of the Ossa Morena Zone, Iberian Peninsula: Tracing the influence of mantlecrust Interaction in ore-forming processes. Economic Geology, 99(5), 965-985.

TRINCHERINI, P., BARBERO, P., QUARATI, P., DOMERGUE, C., LONG, L., 2001. Where do the lead ingots of the Saintes-Mariesde-la-Mer wreck come from? Archaeology compared with physics. Archaeometry, 43(3), 393-406.

TRINCHERINI, P., DOMERGUE, C., MANTECA, I., NESTA, A., QUARATI, P., 2009. The identification of lead ingots from the Roman mines of Cartagena (Murcia, Spain): The role of lead isotope analysis. Journal of Roman Archaeology, 22, 123-145.

VELASCO, F., PESQUERA, A., HERRERO, J., 1996. Lead isotope study of $\mathrm{Zn}-\mathrm{Pb}$ ore deposits associated with the Basque-Cantabrian basin and Paleozoic basement, Northern Spain. Mineralium Deposita, 31(1-2), 84-92.

VILLA, I., 2016. Provenancing bronze: Exclusion, inclusion, uniqueness, and Occam's razor. In: G. Grupe, G. McGlynn, eds. Isotopic Landscapes in Bioarchaeology. Proceedings of the International Workshop " $A$ Critical Look at the Concept of Isotopic Landscapes and its Application in Future Bioarchaeological Research", München, October 13-15, 2014. Berlin - Heidelberg: Springer, pp. 141-155.

WAGNER, T., SCHNEIDER, J., 2002. Lead isotope systematics of veintype antimony mineralization, Rheinisches Schiefergebirge, Germany: A case history of complex reaction and remobilization processes. Mineralium Deposita, 37, 185-197.

WALDHAUSER, J., SMEJTEK, L., FRÁNA, J., 2010. Laténské prospekční (?) aktivity u Brodu na Př́bramsku. Archeologie ve střednich Čechách, $14,281-308$.

WERNER, J., 1979. Spätes Keltentum zwischen Rom und Germanien. München: Verlag C.H. Beck.

ZIEGHAUS, B., 2013. Münzen und Münzenwerkzeuge. In: S. Sievers, M. Leicht, B. Zieghaus, eds. Ergebnisse der Ausgrabungen in Manching - Altenfeld 1996-1999. Die Ausgrabungen in Manching, Band 18, Wiesbaden, pp. 425-568.

ZWICKER, U., GALE, N., GALE, S., 1991. Metallographische, analytische und technologische Untersuchungen sowie Messungen der Bleiisotope an Otto-Adelheid-Pfennigen und Vergleichsmünzen meist aus dem 9.-11. Jahrhundert: Ein Beiträge zur Münzprägung der sächsischen Kaiser. In: G. Hatz, V. Hatz, U. Zwicker, N. Gale, Z. Gale, eds. Otto-Adelheid-Pfennige, Untersuchungen zu Münzen des 10.-11. Jahrhunderts. Commentationes de Nummis Saeculorum IX-XI in Suecia Repertis, Nova Series 17. Stockholm: Royal Swedish Academy of Letters History and Antiquities, pp. 59-146. 
